\title{
THE INTERNAL AUDIT AS FUNCTION TO THE CORPORATE GOVERNANCE
}

The aim of this paper is to show the internal audit in function to the corporate governance. Within the planetary economy, internal auditing is determined as an essential means of the exact management of any business economic resources. Concurrently, corporate governance has received wide attention in recent years, both in practice and in academic research because of the main accounting scandals and large-scale corporate failures. The Institute of Internal Auditors presents that regardless of the reporting relationship the organization chooses, there are primary measures that will ensure that the reporting lines, support and enable the effectiveness and autonomy of the internal audit function. Corporate governance has become an increasingly critical issue after the corporate affairs which occurred all over the world and its specific role in the steadiness of financial intermediaries was highlighted by the intense crisis which impacts the financial markets from the summer of 2007. In fact, for financial intermediaries, the governance chain is all the more important not only because the intermediaries are basically in the business of risk acceptance, but also due to their peculiar role within the economy in the aggregation and transfer of financial resources. Regulation may impact on financial venture taking by financial intermediaries by way of the decision-making process pointed out in the various possible legal structures set forth by the law.

Keywords: Internal audit, audit committee, corporate governance, financial markets, collaborations

Associate Professor, John Naisbitt University, Graduate School of Business Studies, email: joksimovicm@naisbitt.edu.rs

** PhD student, John Naisbitt University, Graduate School of Business Studies 


\section{Introduction}

Corporate governance is the system by which business corporations are observed and controlled.

After the chute of Enron, some regulations, including an emphasis on antifraud and whistleblower provisions and the possible impact on stock prices, have compelled auditors to take a more active role in governance. Boards of directors for all kinds of companies are charged with responsibility for the effectiveness of their organization's internal control systems, in order to promote effective corporate governance. One of the capital governance issues brought to light by the bankruptcy of Enron was the conflict of interest involved with having financial officers of a company both handles and be equity holders of entities that conducted significant business transactions with Enron.

In Europe, there are three different potential board structures: the one-tier board system, characteristic of the UK, Spain and many other countries, the vertical two-tier model, typical of Germany and of the Netherlands in the case of large companies and countries in which companies may choose between diverse systems, such as France and Italy. Since the Global Financial Crisis of 2007-09, the plan and implementation of internal control systems have attracted important academic and professional attention. Much research on the effectiveness and characteristics of internal audit functions has been guided under the sponsorship of the Institute of Internal Auditors Research Foundation (IIARF) and announced in academic and professional journals.

Despite these exertions, there has been a little systematic analysis of how the design of an internal control system has influenced the efficiency and effectiveness of corporate governance processes, principally at financial institutions like insurance associations. The "three lines of defence model" has been used topically to model the interaction among corporate governance and internal control systems. The internal audit role could be viewed as a first line protection against inadequate corporate governance and financial reporting.

With fitting support from the board of directors, audit committee, the internal audit personnel are in the best position to gather information on unsuited accounting practices, unsuitable internal controls, and incapable corporate governance. "Via the years, internal auditing has built up into a highly professional work that stretches to the appraisal of the efficiency and effectiveness of all cycles of a company's actions, both financial and non-financial. These changes have led to the establishment of internal audit departments and became one of the significant units in the most modern companies in the world. The challenges of the global financial market, with its energetic and complex organizations, products and various risks, look for a well-working governance structure to increase the

IFAC (2009): Handbook of International Standards on Auditing and Quality Control, International Federation of Accountants, New York, NY. 
supervision and control of the company. So, the Internal Audit Function (IAF) in the company industry should behave as an independent part of the internal governance, composition and should play a crucial role in the assessment and enhancement of another internal governance incumbency, such as inward control, risk management and within the different governance system and processes. ${ }^{2}$ Also, different regulators endorsed the central position of the IAF.

\section{Statement of the Problem}

Internal audit is a constituent part of the internal control system of financial institutions, at the heart of the company is the audit role. This is evidenced by the fact that all other departments are linked by the internal audit department. The significance of the internal audit system cannot be overemphasized since organizations have recognized internal audit function as a tool for securing effective workings of the internal control system.

The internal audit is one of the important modes for management to confirm and verify the compliance of administrative units in the financial and administrative policies, legislatures, financial and administrative systems and the adopted public policies. The internal audit has been developed and magnified the attention to it and standards, guidelines, and moral constitutions had been issued and became one of the influential units in most companies in the world.

This study is theoretically founded on two main theories; namely the agency theory and institutional theory. By definition, the agency theory describes the relationship between contract parties under which "one or more persons (principal) who is the economic resource owner engage another person (agent) who is charged with using and controlling these resources to carry out some service on their behalf, which involves delegating some decision-making controller to the agent." However, this theory proposes that such kind of relationship between the principal or manager and the agent is not very firm for many reasons.

First, the agents may not be trusted to take the best action because they can act in their own interests and they usually have more information than managers leading to information asymmetry. Thus, different internal and external corporate governance mechanisms have been suggested to limit agency costs and make an approach between the manager's interest and agent's interest simultaneously.

Moreover, separating ownership from management functions such as controlling corporate resources can cause a lot of conflicts. Mainly, the manager could misuse the company's resources and go through risk investments.

\footnotetext{
2 See more: Mennicken, A.N.D.R.E.A. and Power, M. (2013): Auditing and corporate governance, The Oxford handbook of corporate governance, pp. 308-327.

3 IFAC (2009): Handbook of International Standards on Auditing and Quality Control, International Federation of Accountants, New York, NY.
} 
Accordingly, IAF assists the board of directors and audit committee to reduce agency conflicts through monitoring and supervising both, the top managements and the internal control system.

On the other hand, the institutional theory highlights the importance of organizational structures in terms of conformity to rules and social accountability.

Practically, the board of directors plays two primary roles in developing the organizational structure and performance of companies.

First, the board of directors establishes linkage between the company and the external environment. Secondly, it assists IAF to oversee the management and administrative procedures that lead to the company's performance.

Respectively, the combination of these two theories would be helpful in better understanding of board functions and companies performance. As the agency theory encourages boards to improve company's performance through corporate governance and monitoring principals, the institutional theory emphasizes the significance of administrative practices and adherence to regulations to improve the organizational effectiveness.

Based on the previous discussion, a theoretical framework is developed to study the direct influence of the IAF on the company's performance in terms of the Basel committee's IAF principles. Despite the increasing focus on internal audit, there have been a limited number of earlier reviews of the internal auditors' objectivity literature. The purpose of this paper is to discuss the concepts of independence and actuality from the perspective of internal auditing and to recommend ideas for future research.

\subsection{Objectives of the Study}

The objective of this study is to propose a theoretical order for internal control systems in organizations, through reviewing literature related to the implementation of the internal audit function and its effect on corporate governance for a company in terms of the Basel Committee principles on Banking Supervision. In addressing the questions, this study examines factors such as: • internal audit structure, which include team size; composition, in terms of experience and expertise; and whether combined assurances or collaborations are conducted; $\bullet$ involvement of $\mathrm{AC}$ in the IAF activities; in the reviews of audit planning, audit execution, and actions on recommendations of internal audit; and • internal audit performance impacts on corporate governance in four key dimensions; legal framework/corporate policies, management improvements, accountability, and information and transparency. The end result of an internal audit is the audit recommendations.

The recommendations that are acted upon by management may help to further strengthen the various dimensions of corporate governance. Management decisions to act on these recommendations may provide an indication of the effectiveness of internal audit. 
In today's business environment, it becomes more important preventive activities of internal audit. Internal audit activities are intended to support the management in anticipation of future risks and proposing composition of the internal controls which they will be limited on time. In the context of corporate governance, internal audit must evaluate and make appropriate recommendations to improve the process of corporate governance in achieving the following objectives - the fulfillment of appropriate ethical values in the organization - management efficiency of the organization, analysis of risk information and control at the appropriate levels in the organization- coordination activities and communication between the Board, the internal and external auditors and management.

The research topic of the article will refer to the consideration of the impact of the internal audit on the corporate governance. Internal auditing is an independent, objective assurance and consulting activity labeled in a way that adds value to the organization and improves an organization's operation. It helps the organization in meeting its goals and improve management controls, risk management, and corporate governance. Activities of corporate governance to ensure that the critical information coming to the Board complementary, accurate and timely in order to deliver high -quality decision- making. The role of internal audit in the corporate governance stems from the fact that the internal audit determines reality, integrity, and reliability of operational and financial information on which to make decisions at all levels of governance.

Theoretical fundamentals in this article refer to models that will be used during the research within corporate governance. By the standards of internal audit shall evaluate and contribute to the improvement of risk management and corporate governance. Therefore, there is a need for continuous development of new approaches to internal auditing, designing new products and audit services, and comparable to the increasingly complex demands placed upon corporate governance. Basic concepts of research management risks, controls, and corporate governance.

An operational definition of the subject of research means to separate main parts ( structural factors) research process, namely: internal audit and corporate governance. A further operation of internal audit will be classified into an internal and external audit. While corporate governance will be explored in terms of financial management.

Spatial definition of the subject of research includes a double observation. One definition refers to the internal audit of the company. The second definition refers to the internal audit which will be studied in the corporation at different levels of governance. The area in which the research will be carried out includes European Union territory and the territory of the other European countries and companies that operate in them.

Time frame subjects of investigation cover the period of internal auditing before and after the global economic crisis and its impact on today's corporate governance. 
Disciplinary definition of the subject of research indicates that research has an interdisciplinary character and to economics, monetary economics, international system of accounting, auditing, audit, business finance and audit market operations.

The scientific goal of the research will be the scientific discovery of mutual connections and relationships that exist between internal audit and corporate governance. Will scientific discoveries come through the scientific descriptions, classifications, typologies, concepts, and processes which are the subject of research?

Social objective of the research will be multifaceted and reflected in the assessment: the nature of internal audit corporate governance; controlling influence on corporate governance, ways of implementation of internal audit in the corporation and contributes to the internal audit corporate governance.

The general hypothesis in the paper in the research are: As the independence and objectivity of internal auditors are bigger, and effectiveness of the internal audit system of corporate governance is increased. Based on the previously defined problems and objects of research formed the following working hypothesis: As internal audit recommendations more respect, it is a quality of corporate governance by better management.

The methodology of research used in this paper is based on a combination of the inductive with abstract research that is designed to help us in the obtaining of verifiable knowledge with a strong contribution to the development of the scientific knowledge in this area.

In order to touch our research topics, we will proceed at a rough documentation over the most recent publications: articles in journals, governmental acts, reports, ideas, recommendations issued by international professional formations that coordinate internal audit activity.

I focused on the analysis of the opinions and information identified by using descriptive and technical documentation and non-participating observation method, which, contributes a series of advantages because the information can be reached easily and at midget expense when the respondents are not willing to impart it.

The final goal was to recognize the main coordinates that will distinguish the next evolution and development of internal audit function and their impact on the corporate governance.

\subsection{The Scope and Limitation of the Study}

With regard to the object of this paper and with special reference to the finance sector, it is possible to develop two altitudes of analysis. The first is dedicated to the policy and the functioning of corporate governance in Europe and within the rest of the world. The second level of analysis concerns the finance organization that, independently from the central formal regulation, can implement virtuous practice and adopt internal instruments to better manage the system of risks. 
As a result, it reinforces the pertinence of having a highly qualified and experienced management, the most convenient internal and external auditors and, besides, that supervisors focus more watchfulness on strengthening internal control systems and steadily evaluating their effectiveness. Generally, studies concerning internal audit have focused on general analysis.

The reason for that is that cross- country analyses have major downsides, because of the differences in social, legal and regulatory contexts. One of the most difficult obstacles to overpower is getting research access within the organization. The biggest limitation in this instruct was the confidentiality of internal audit reports, thus I was not able to get them from any commercial company.

Therefore, we had to limit analysis to the relationships among the internal audit department and formal corporate governance structures as they are described in openly present information and interviews. ${ }^{4}$

Since the research question is complex and needs to be open to interpretations, I used the qualitative research method, which is usually concerned with words rather than numbers, putting an emphasis on the point of view of the Basel Committee on Banking Supervision so as The Institute of Internal Auditors (IIA).

\section{Research on the Internal Audit Function and Corporate Governance}

There are different answers to the question of internal audit activities are the most significant for the corporate company. Research conducted by the Institute of Internal Auditors, among other things, dealt with the question. From 1972 to the present investigations are carried out in different time series. A number of enterprises in the countries surveyed varied from 2 companies in 1972 and 13.582 company in 2010. Also a lot of the number of countries with steadily increasing from one to as many as 107 countries. The results of this research have been published in five different reports, including Report I: Characteristics of an Internal Audit Activity examines the characteristics of the internal audit activity, including demographics, staffing levels, and reporting relationships; Report II: Core Competencies for Today's Internal Auditor identifies and discusses the most important competencies for internal auditors. It also addresses the adequacy, use, and compliance with The IIA's Standards; Report III: Measuring Internal Auditing's Value focuses on measuring the value of internal auditing to the organisation; Report IV: What's Next for Internal Auditing? provides forward-looking insight identifying perceived changes in the roles of the internal audit activity over the next five years; Report V: Imperatives for Change: The IIA's Global Internal Audit Survey in Action contains conclusions, observations, and recommen-

$4 \quad$ See more: Hoitash, U., Hoitash, R. and Bedard, J.C. (2009): Corporate governance and internal control over financial reporting: A comparison of regulatory regimes, The accounting review, 84(3), pp.839-867. 
dations for the internal audit activity to anticipate and match organizations' fastchanging needs to strategically position the profession for the long term.

\subsection{Redefining Internal Audit Performance}

In view of the recent global repeal of 2009-10, when investments made by financial institutions proved insecure and practically triggered a financial meltdown that required strong input and investment by most democratic governments, the call for internationally regulated and well-audited financial institutions are bigger than ever.

Therefore, financial institutions have started to centralize on rigorous internal audit processes set to an internal audit team that keeps regular control selfassessments. The recent financial crisis revealed fewest corporate governance failures in the domain, both in the United States and in Europe. The Boards of particular key financial institutions were caught to have been unable either to monitor risk management systems and executive earnings effectively ( the United States and the United Kingdom).

Italy also experienced its own incidents of governance shortcomings, both in a large company and in a medium-sized company. Sound corporate governance is risky for a well-functioning company model and for the integrity of financial markets.

Corporate governance designates the systems, principles, and processes by which company are governed and influences the behavior of their employees, clients, and shareholders. ${ }^{5}$

Internal audit can be defined as an independent activity objectively, confirmatory, and consultant established to add value and repair the organization's operations and by helping them to achieve their targets through a systematic and disciplined way to evaluate and improve the effectiveness of risk management and control processes and governance. ${ }^{6}$

The financial settlements accountant has the responsibility of developing systematic settlements to assist management in the performance of the services of the institution while the financial institution's auditor has between other duties the complementary role to examine whether management actually performs that efficiently.

The financial institution's auditor has to settle himself that the presented have been prepared in accordance with statutory and constitutional requests and regulation and that proper accounting practice has been observed in their Com-

$5 \quad$ Bank for International Settlements (2015): Guidelines Corporate governance principles for banks, Basel Committee on Banking Supervision, (BCBS) July 2015

6 See more: Soh, D.S. and Martinov-Bennie, N. (2011): The internal audit function: Perceptions of internal audit roles, effectiveness and evaluation, Managerial Auditing Journal, 26 (7), pp. 605-622. 
pilation. We can see on the Table no 1 and Graphic no 1 the top seven activities to be performed in the next five years. Analysis of the seven internal audit activities that are expected to be performed in the next five years, according to respondents' organizations' ownership structure, shows that the overall average, we can see that corporate governance reviews have $23 \%$, and disaster recovery testing and support in the company have just $18 \%$. But other activities have between $19 \%$ and $20 \%$.

Table 1. Presents of Top Seven Activities to Be Performed in the Next Five Years (Percentage of Respondents)

\begin{tabular}{|l|c|}
\hline & $\begin{array}{c}\text { Overall } \\
\text { Average }\end{array}$ \\
\hline Corporate governance reviews & $23 \%$ \\
\hline Audits of enterprise risk management processes & $20 \%$ \\
\hline Reviews addressing linkage of strategy and company performance & $20 \%$ \\
\hline Ethics audits & $19 \%$ \\
\hline Migration to International Financial Reporting Standards (IFRS) & $19 \%$ \\
\hline Social and sustainability audits & $19 \%$ \\
\hline Disaster recovery testing and support & $18 \%$ \\
\hline
\end{tabular}

Source: Authors research conducted to five reports by the Institute of Internal Auditors

When this data on Graphic no 1 compared with internal audit staff (not managers or supervisory level staff), a higher percentage of CAEs have expectations that all seven activities will be performed in the next five years.

With the growing value and complexity of financial institutions in the recent years, the importance of the internal audit has agreeably increased so that it is today the main factor in establishing the quality of the financial institutions' internal control and its uprising has made a formidable contribution to the improvement of the financial institution's management. ${ }^{7}$

At the essence of a company, is the audit function, this is evident by the fact that all other departments are connected with the internal audit department. Organizations have accorded internal audit as a tool for providing an effective working of the internal control system. Efficient perpetration entails achieving goals with the minimum loss of resources that are making the best usage of resources that is making the best use of money, time materials and people. ${ }^{8}$

7 Wilson Kamit (2008): Role of internal auditors in the Bank and supervised institutions, the 5th annual conference "Harnessing internal auditors for today's challenges", hosted by the Institute of Internal Auditors - PNG, Port Moresby, 12 June 2008

$8 \quad$ Mayhew, B.W. and Wilkins, M.S. (2003): Audit firm industry specialisation as a differentiation strategy: evidence from fees charged to firms going public, Auditing: A Journal of Practice \& Theory, Vol. 22, September, pp. 33-52. 
Graphic 1. Top Seven Activities to Be Performed in the Next Five Years (Percentage of Respondents)

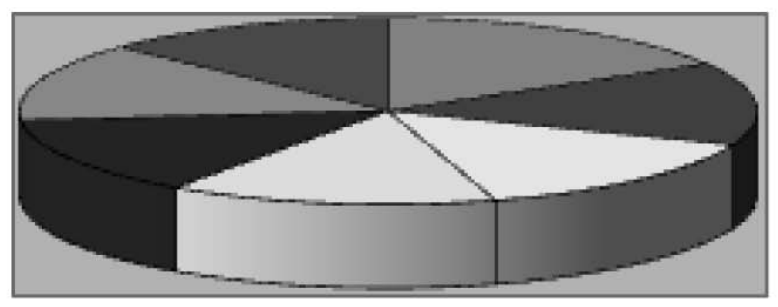

$\square$ Corporate governance reviews

$\square$ Audits of enterprise risk

$\square$ Reviews addressing linkage of perfomance

$\square$ Ethics audits

$\square$ Migration to International

Financial

$\square$ Social and sustainability audits

$\square$ Disaster recovery testing and support

Source: Authors research conducted to five reports by the Institute of Internal Auditors

\subsection{The Internal Audit Function}

The Internal Audit Function represents a unique research setting for at least four important reasons. First, as noted above, the Internal Audit Function often serves parties integrally involved in governance processes, such as the council of directors, audit committee, external auditor, and senior management.

However, the IAF also serves and adds worth to those who are governed, such as management and individual organizational units such as treasury, information technology management, and operations. As a result, IAFs are often called upon to serve two masters: those primarily responsible for governance and those being governed. This unique relationship raises interesting research opportunities for those interested in internal audit research and the important role the IAF plays in adding value to governance processes. Next, many activities performed by IAFs can be incorporated into an organization's control structure. For example, the IAF frequently performs significant monitoring activities that could be incorporated into an organization's control process. This often raises questions about the proper role of the IAF - serving as a direct part of the control system versus regarding the effectiveness of controls. Third, the IAF may be sourced internally within the organization or could be outsourced to a third-party.

However, internal audit outsourcing is unique in that the major purveyors of such services are the external audit firms. Subsequently, outsourcing is unique in the sense that a major part of the governance structure is not part of the organization. ${ }^{9}$

9 See more: Elbardan, H., Ali, M. and Ghoneim, A. (2015): The dilemma of internal audit function adaptation: The impact of ERP and corporate governance pressures, Journal of Enterprise Information Management, 28(1), pp.93-106. 
We have to see whether outsourcing creates additional independence and improves the effectiveness of the governance process as a whole, or whether the broad organizational view developed by sourcing internal audit internally enhances governance. The opportunities for research are rich. We hope that this discussion will help additional research on the IAF and governance.

On the Graphic no 2 and no 3 authors in the paper's research conducted to five reports by the Institute of Internal Auditors Governance/Control Context by Internal Audit Activity Age apply now and will apply in 5 years.

Table 2. Governance/Control Context by Internal Audit Activity Age Applies now

\begin{tabular}{|l|c|}
\hline & $\begin{array}{c}\text { Overall } \\
\text { Average }\end{array}$ \\
\hline Internal auditing is required by law or regulation where the organization is based & $70 \%$ \\
\hline The organization complies with a corporate governance code & $80 \%$ \\
\hline The organization has implemented an internal control framework & $82 \%$ \\
\hline The organization has implemented a knowledge management system & $46 \%$ \\
\hline
\end{tabular}

Source: Authors research conducted to five reports by the Institute of Internal Auditors

On the Table no 2 and Graphic no 2 we can see the governance/control context by Internal Audit Activity age applies now that the overall average. We can see that The organization has implemented an internal control framework have $82 \%$, and the organization has implemented a knowledge management system in the company have just $43 \%$. But other activities have between $70 \%$ Internal auditing is required by law or regulation where the organization is based and The organization complies with a corporate governance code is $80 \%$.

Graphic 2. Governance/Control Context by Internal Audit Activity Age Applies now
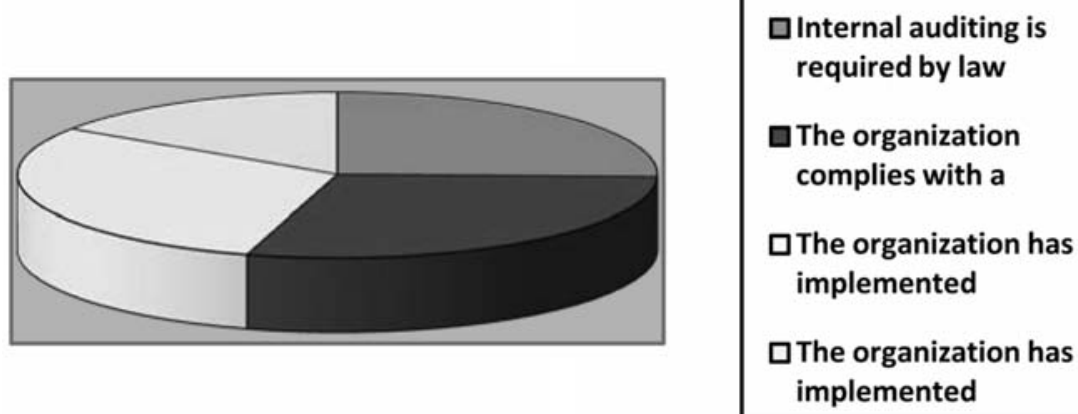

Source: Authors research conducted to five reports by the Institute of Internal Auditors 
Table 3. Governance/Control Context by Internal Audit Activity Age Will apply

\begin{tabular}{|l|c|}
\hline \multicolumn{1}{|c|}{ in 5 years } & $\begin{array}{c}\text { Overall } \\
\text { Average }\end{array}$ \\
\hline Internal auditing is required by law or regulation where the organization is based & $73 \%$ \\
\hline The organization complies with a corporate governance code & $90 \%$ \\
\hline The organization has implemented an internal control framework & $93 \%$ \\
\hline The organization has implemented a knowledge management system & $71 \%$ \\
\hline
\end{tabular}

Source: Authors research conducted to five reports by the Institute of Internal Auditors

The Table no 2 and Graphic no 2 show the governance/control context by Internal Audit Activity age will apply in 5 years that the overall average. We can see that The organization has implemented an internal control framework have 93\%, and the organization has implemented a knowledge management system in the company have just $71 \%$. But other activities have between $73 \%$ Internal auditing is required by law or regulation where the organization is based and The organization complies with a corporate governance code is $90 \%$.

On the Table no 4 we can see comparative governance/control context by internal audit activity age applies now and apply in the next five years. The table shows that the overall average internal audit activity age applies a similar range between activities. Internal auditing is required by law or regulation where the organization is based is in the range of $70 \%$ to $73 \%$, the organization complies with a corporate governance code is in the range of $80 \%$ to $90 \%$, the organization has implemented an internal control framework is in the range of $82 \%$ to $93 \%$, the organization has implemented a knowledge management system is in the range of $46 \%$ to $71 \%$. It can be concluded that the organization has implemented a knowledge management system have the biggest range between $46 \%$ to $71 \%$, and Internal auditing is required by law or regulation where the organization is based have the smallest range between $70 \%$ to $73 \%$.

Graphic 3. Governance/Control Context by Internal Audit Activity Age Will apply in 5 years
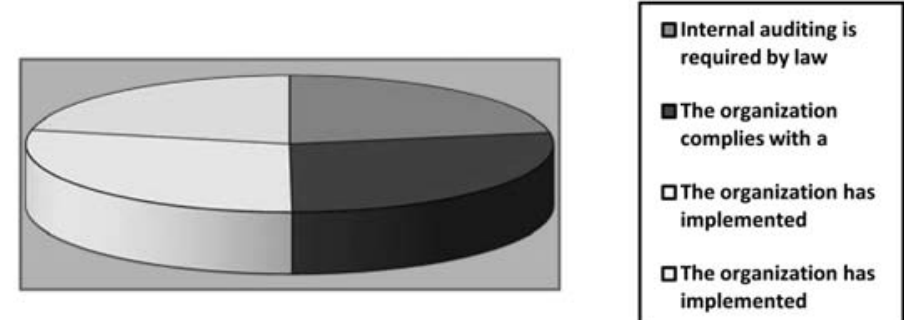

Source: Authors research conducted to five reports by the Institute of Internal Auditors 
Table 4. Governance/Control Context by Internal Audit Activity Age Applies now and Will apply in 5 years

\begin{tabular}{|l|c|c|}
\hline \multirow{2}{*}{} & Applies now & Will apply in 5 years \\
\cline { 2 - 3 } & \multicolumn{2}{|c|}{ Overall Average } \\
\hline $\begin{array}{l}\text { Internal auditing is required by law or regulation where the } \\
\text { organization is based }\end{array}$ & $70 \%$ & $73 \%$ \\
\hline The organization complies with a corporate governance code & $80 \%$ & $90 \%$ \\
\hline The organization has implemented an internal control framework & $82 \%$ & $93 \%$ \\
\hline The organization has implemented a knowledge management system & $46 \%$ & $71 \%$ \\
\hline
\end{tabular}

Source: Authors research conducted to five reports by the Institute of Internal Auditors

\section{Conclusion}

Good corporate governance practices of the company are essential to maintaining the sound and proper functioning of the financial sector. It is frequently argued that company failure might comprehend systemic risks and have a huge negative impact on depositors, other stakeholders, and the economy as a whole.

This paper examines the internal audit in function to the corporate governance in 107 states between 1972 and 2010. Also general hypothesis in the paper in the research are: As the independence and objectivity of internal auditors are bigger, and effectiveness of the internal audit system of corporate governance is increased is confirmed, and the following working hypothesis: As internal audit recommendations more respect, it is a quality of corporate governance by better management is also confirmed.

The interests of depositors deserve special attention in a discussion of company corporate governance. The international corporate governance debate has mostly focused on (i) weak shareholders and dominant executives in the United States, (ii) insufficiently engaged shareholders in the United Kingdom, and (iii) powerful but conflicted block holders in most other countries.

The traditional conflicts between shareholders, managers, and boards are also present in the company. Many companies, including the largest, are limited liability stock corporations. Like any other type of corporation, they can be distressed by board failure on strategy and oversight, misaligned or perverse incentives, empire building, conflicts of interest, weaknesses in internal controls, incompetence, and fraud. The brief analysis here proposed has the objective to attract the attention towards the multi-perspective utility of the regulation within the financing system.

This phenomenon takes place for different reasons. First, the presence of formal rules within the company especially considering the complexity of the financial sector contributes to the perception of the importance of informative 
instruments for the continuous monitoring of the financial and economical balance of the organization. At the same time, the authorities' role emerges to promote the autonomous and creative spirit when applying the rules.

This happens especially considering the necessity of adapting the prevention of risks with the special characters of the organization and its economic activity.

The rules system is, in fact, fundamental for the social order; however, this balance can be achieved in a different combination of internal and external authorities, a self- ruling, promoted by the competitive processes of the functioning marketplace.

It is from this perspective that internal control systems are considered the product of deep reflection of governance: it represents the basis of a wide estimation for the single operative instruments and for the general culture of the risk control. ${ }^{10}$

The internal audit function is a substantial element of the control infrastructure and must be capable of inspecting any aspect of corporate operations to determine whether policies and procedures are adequate, secure, and functioning as intended, or whether new controls are needful in order to close loopholes or correct errors. Again, such units must reflect an appropriate level of independence in order to be effective. They also have to be properly staffed; this means hiring professionals with adequate technical skills and stature to perform the job properly. Unfortunately, in some systems internal audit teams are not given the sufficient resourcing or authority, meaning the quality, quantity, and depth of work can suffer. Over the past few years, it has become evident that internal audit controls do not always work as intended and can fail to detect problems, mistakes, or fraud (sometimes for extended periods of time). They may even contribute to control problems.

In these days of this global economic crisis, it becomes clear that the importance of internal audit in companies will be increasingly higher. Developing the skills of identifying key risks, particularly those arising from the global economic downturn, internal audit is seen as a key element in the fight for the combating of the negative effects of the current economic crisis but also to prevent other such negative phenomena. Internal audit has now the chance to change its role in the process of risk management into a more strategic outcome which would not only prevent future catastrophes of this kind but also will make the company operate more efficiently.

Potential causes may be either internal audit did not give the adequate importance to risk management either the internal auditors were not allowed to put the right questions or were ignored or recommendations made by them in order to improve the risk management strategy were totally ignored by the management of the company.

$10 \quad$ See more: Krishnan, J. (2005): Audit committee quality and internal control: An empirical analysis. The accounting review, 80(2), pp. 649-675. 
On the other hand, even if the internal audit would be conducted with maximum efficiency evaluation of the effectiveness of risk management, it would not be able to prevent the crisis without the support of the overall management and the audit committee of the company. In this context, the importance of effective communication channels between management, audit committee and internal audit becomes more than obviously and must operate in a coherent whole that truly contributes to preventing the possible future economic crisis.

\section{Literature:}

- Marco Allegrini, Giuseppe D’Onza, Rob Melvile, Gerrit Sarens, Georges M. Selim (2011): The IIA's Global Internal Audit Survey: A Component of the CBOK Study What's Next for Internal Auditing? Report IV, The Institute of Internal Auditors Research Foundation (IIARF).

- International Federation of Accountants (IFAC) (2009): Handbook of International Standards on Auditing and Quality Control, International Federation of Accountants, New York, NY.

- Bank for International Settlements (2015): Guidelines Corporate governance principles for banks, Basel Committee on Banking Supervision, (BCBS) July 2015.

- Bank for International Settlements (1999): Enhancing Corporate Governance for Banking Organizations, Basel Committee on Banking Supervision Basel, (BCBS), September 1999.

- Bank for International Settlements (1998): Framework for internal control systems in banking organisations, Basel Committee on Banking Supervision Basel, (BCBS), Basel September 1998.

- Collier, P. and Zaman, M. (2005): Convergence in European corporate governance: The audit committee concept, Corporate Governance: An International Review, 13(6), pp.753-768.

- Hoitash, U., Hoitash, R. and Bedard, J.C. (2009): Corporate governance and internal control over financial reporting: A comparison of regulatory regimes, The accounting review, 84(3), pp.839-867.

- Elbardan, H., Ali, M. and Ghoneim, A. (2015): The dilemma of internal audit function adaptation: The impact of ERP and corporate governance pressures, Journal of Enterprise Information Management, 28(1), pp.93-106.

- Eulerich, M., Theis, J., Velte, P. and Stiglbauer, M. (2013): Self-Perception of the Internal Audit Function within the Corporate Governance System, Empirical Evidence for the European Union. Problems and Perspectives in Management, 11(2), pp.57-72. 
- $\quad$ Larcker, D.F., Richardson, S.A. and Tuna, I. (2007): Corporate governance, accounting outcomes, and organisational performance, The Accounting Review, 82(4), pp.963-1008.

- Mayhew, B.W. and Wilkins, M.S. (2003): Audit firm industry specialisation as a differentiation strategy: evidence from fees charged to firms going public, Auditing: A Journal of Practice \& Theory, Vol. 22, September, pp. 33-52.

- Mennicken, A.N.D.R.E.A. and Power, M. (2013): Auditing and corporate governance, The Oxford handbook of corporate governance, pp. 308-327.

- Wilson Kamit (2008): Role of internal auditors in the Bank and supervised institutions, the 5th annual conference "Harnessing internal auditors for today's challenges", hosted by the Institute of Internal Auditors - PNG, Port Moresby, 12 June 2008

- Krishnan, J. (2005): Audit committee quality and internal control: An empirical analysis. The accounting review, 80(2), pp. 649-675.

- Guidance on Risk Management (2014): Internal Control and Related Financial and Business Reporting, September 2014.

- Global Perspectives (2017): Elevating Internal Audit's Strategic Impact, Issue 6, January 2017. https:/global.theiia.org/knowledge/Public\%20Documents/ GPI-Elevating-Internal-Audits-Strategic-Impact-English.pdf

- Gene Imhoff, Accounting Quality (2003): Auditing and Corporate Governance, Accounting Horizons 17(s-1), January 2003.

- Gramling, A.A., Maletta, M.J., Schneider, A. and Church, B.K. (2004): The role of the internal audit function in corporate governance: A synthesis of the extant internal auditing literature and directions for future research, Journal of Accounting literature, 23, p.194.

- Leen Paape (2007): Corporate Governance: The Impact on the Role, Position, and Scope of Services of the Internal Audit Function, Erasmus Research Institute of Management (ERIM) RSM Erasmus University / Erasmus School of Economics, Erasmus University Rotterdam.

- Paape, L., Scheffe, J. and Snoep, P. (2003): The relationship between the internal audit function and corporate governance in the EU-a survey, International Journal of Auditing, 7(3), pp.247-262.

- Soh, D.S. and Martinov-Bennie, N. (2011): The internal audit function: Perceptions of internal audit roles, effectiveness and evaluation, Managerial Auditing Journal, 26(7), pp. 605-622. 
Dr Marijana Joksimović, vaNRedni PRofessor, Fakultet za poslovne studije, Džon Nezbit Univerzitet

Master Alseddig Ahmed,

student doktorskih studija Fakulteta za poslovne studije, Univerzitet Džon Nezbit

\section{INTERNA REVIZIJA \\ U FUNKCIJI KORPORATIVNOG UPRAVLJANJA}

Cilj ovog rada je da prikaže internu reviziju u funkciji korporativnog upravljanja. U okviru planetarne ekonomije, interna revizija je određena kao osnovni način za precizno upravljanje svim ekonomskim resursima. Istovremeno, korporativno upravljanje je dobilo ogromnu pažnju u poslednjih nekoliko godina, kako u praksi, tako i u naučnim istraživanjima, pre svega zbog bitnih računovodstvenih skandala $i$ velikih korporativnih neuspeha. Institut za internu reviziju preporučuje da bez obzira kakvo je izveštavanje u organizaciji, postoje određene primarne mere koje će osigurati da se na adekvatan način podržavaju i omogućavaju efikasnost $i$ nezavisnost funkcije interne revizije. Korporativno upravljanje postaje ključno pitanje nakon dešavanja poslednjih godina na svetskom tržištu. Specifična uloga u stabilnosti finansijskih posrednika veoma je naglašena posle krize koja utiče direktno na finansijska tržišta od leta 2007. godine, a u stvari, finansijski posrednici u lancu upravljanja postaju sve važniji, ne samo zato što posrednici u poslovanju prihvataju sve veći rizik, nego i zbog njihove specifične uloge u privredi prilikom transfera finansijskih sredstava. Propisi mogu uticati na uzimanje finansijskih ulaganja od finansijskih posrednika putem procesa donošenja odluka u različitim mogućim pravnim strukturama utvrdenim zakonom.

Ključne reči: Interna revizija, Komitet za racunovodstvo, Korporativno upravljanje, finansijka trzista, saradnje. 